\title{
İlahiyat Fakültesi Öğrencilerinde Kadının Örtünmesine ilişkin Algılar
}

\author{
Kenan SEVINÇ ${ }^{*}$
}

Illahiyat Fakültesi Öğrencilerinde Kadının Örtünmesine ilişkin Algılar

\section{Özet}

Dünyada Müslüman kadınlar arasında başörtüsü, türban, peçe, çarşaf ve burka gibi farklı örtünme biçimleri vardır ve bunlar ülkeden ülkeye değişiklik göstermektedir. Bu çalışma, ilahiyat fakültesi öğrencilerinin Türkiye'de genel popülasyona kıyasla örtünme tercihlerini, örtünmeyle ilgili düşüncelerini ve örtünme nedenlerini ele almaktadır. Araştırma, 2017 ylında 505 ilahiyat fakültesi öğrencisine anket uygulanarak gerçekleştirilmiştir. Hangi örtünme biçiminin İslam'a daha uygun olduğu sorulduğunda katılımcıların cevapları en kapalı örtünme biçimden en açık örtünme biçime doğru şöyle sıralanmıştır: burka $(\% 3,7)$, peçe $(\% 8,2)$, çarşaf $(\% 20,2)$, türban $(\% 61,3)$, başörtüsü $(\% 4,7)$, ve açık $(\% 1,9)$. Araştırma bulguları, ilahiyat öğrencilerinin genel popülasyona göre ve erkek öğrencilerin kadın öğrencilere göre daha kapalı örtünme biçimlerini İslam'a daha uygun bulduklarını ve en yüksek oranda $(\% 37,2)$ gelenek ve görenekleri örtünme sebebi olarak gördüklerini ortaya koymaktadır.
Perceptions of Theology Students on Women's Covering

\section{Abstract}

There are different styles of covering among Muslim women in the world, such as the hijab, al-amira, niqab, chador and burqa. These styles of covering vary from country to country. In this study, it is researched that the headscarf style preferences of the theology faculty students compared to the general population in other Muslim countries and in Turkey, their considerations of covering the woman, and the reasons for covering. The research was conducted in 2017 by applying a questionnaire to 505 theology faculty students. When asked which type of covering is more appropriate for Islam, the answers of the participants were as follows: burqa (3.7\%), niqab (8.2\%), chador (20.2\%), al-amira (61.3\%), hijab (4.7\%) and none (1.9\%). The findings show that as compared to general population, theology faculty students see more covered styles as more appropriate for Islam. Also, male students see more covered styles as more appropriate for Islam compared to females. The findings of the study reveal that the students see the tradition and customs as the reason for the covering (37.2\%).

Key Words: Theology, Woman, Covering, Headscarf, Islam

Anahtar Kelimeler: İlahiyat, Kadın, Tesettür, Başörtüsü, İslam.

1. Giriş

Birçok din, müntesiplerinden giyim konusunda belli kurallara uymalarını bekler. Sabiiler beyaz kıyafetleri, Caynistler bazen kıyafetsiz olmayı, Budistler sarı veya turuncu elbiseleri tercih etmektedir. Ortodoks Yahudiler ve bazı Hristiyan mezhepler ise kadınların başlarını örtmeleri istemektedir (Görmez, 2001). Aynı şekilde İslam dini de müntesipleri için belli giyim kuralları belirlemiştir. Giyim konusunda çoğunlukla referans gösterilen iki ayet şöyledir:

*Kenan SEViNÇ, Yrd.Doç.Dr.,Çanakkale Onsekiz Mart Üniversitesi,Felsefe ve Din Bilimleri Bölümü,kssevinc@gmail.com 
Mü'min kadınlara da söyle, gözlerini haramdan sakınsınlar, ırzlarını korusunlar. (Yüz ve el gibi) görünen kısımlar müstesna, zînet (yer)lerini göstermesinler. Başörtülerini ta yakalarının üzerine kadar salsınlar. Zinetlerini, kocalarından, yahut babalarından, yahut, kocalarının babalarından yahut oğullarından, yahut üvey oğullarından, yahut erkek kardeşlerinden, yahut erkek kardeşlerinin oğullarından, yahut kız kardeşlerinin oğullarından, yahut müslüman kadınlardan, yahut sahip oldukları kölelerden, yahut erkekliği kalmamış hizmetçilerden, yahut da henüz kadınların mahrem yerlerine vakıf olmayan erkek çocuklardan başkalarına göstermesinler. Gizledikleri zinetler bilinsin diye ayaklarını yere vurmasınlar. Ey mü'minler, hep birlikte tövbe ediniz ki kurtuluşa eresiniz! (Nur, 31).

Ey Peygamber! Hanımlarına, kızlarına ve müminlerin kadınlarına söyle, bedenlerini örtecek elbiselerini giysinler. Bu onların tanınıp incitilmemelerine de daha uygundur. Şüphesiz Allah çok bağışlayıcıdır, çok merhamet edicidir. (Ahzab, 59).

Bu ayetlerle ilgili dikkat çeken iki nokta vardır. Birincisi, bu ayetlerin doğrudan kadınlara hitap etmesidir. Her ne kadar erkeklerin giyimine dair gelenek içinde bazı kurallar belirlenmiş olsa da Müslüman toplumlarda dine uygun giyinmek denildiğinde çoğunlukla kadının örtünmesi akla gelmektedir. Bu durumda, günümüz Müslüman toplumlarda kadınların örtünmelerinin cinsiyetçi bir yönü olup olmadığı ve kadın hakları konusunda sorunlar yaşanıp yaşanmadığını tartışması başlamaktadır. İslam'da kadın hakları konusu ele alındığında, birçok Müslüman yazar, cahiliye Arap toplumunda (İslamiyet öncesi) kadının konumunu ele alarak, kız çocuklarının canlı canlı toprağa gömülmesini, evlenme boşanma konusunda kadınların yaşadığı mağduriyetleri, kadınların mirastan pay almaması gibi örnekleri gösterip, İslamiyet'le birlikte kadın haklarında büyük bir iyileşme olduğunu iddia etmektedir (Bkz. Tozduman, 1991; Dikmen, 1983; Yılmaz, 2007; Akdemir, 1997). İslam'ın erkeklerin yanında kadınları da doğrudan muhatap alması, onların çeşitli hakları olduğunu söylemesi, erkeklerin kadınlara karşı sorumlulukları olduğunu salık vermesi, kadınlara miras hakkı tanıması ve benzeri birçok hüküm, İslam'ın ortaya çıtığı dönem ve coğrafya itibariyle devrimsel bir gelişmedir (Armaner, 1961; Eskicioğlu, 1994; Ateş, 1997; Akgül, 1998; Akdemir, 1997, s. 252-253; Özek, 2013). Fakat günümüzde Müslüman çoğunluğun yaşadığı ülkelerde kadın hakları konusunda çeşitli sorunların yaşandığı, birçok sosyal bilimcinin ortak kanaatidir. World Economic Forum (2016) tarafından oluşturulan The Global Gender Gap Report verilerine bakıldığında, Müslüman çoğunluğa sahip ülkelerin, kadın-erkek eşitliği sıralamasında listenin sonlarında yer aldığı görülmektedir. Bazı bilim insanları, Ortadoğu'da cinsiyet eşitsizliğinin dini inançlardan kaynaklandığını düşünmektedir (Bkz. Küçük, 2013). Buna karşın diğer bazıları, cinsiyet eşitsizliğinin İslam'dan değil, kültürün de etkisiyle oluşmuş yanlış dini yorumlardan kaynaklandı̆̆ını iddia etmektedir (Bkz. Özdeş, 2008). Sebebi ne olursa olsun, günümüzde Müslüman toplumlarda kadın haklarının ihlal edildiği yönünde bir kanaat oluşmuştur. Yapılan çeşitli araştırmalarda, Müslümanlara karşı önyargılı ve ayrımcı tutum sergileyen bireylerin, Müslümanlara yönelik ayrımcı tutumlarının gerekçeleri sorulduğunda birçok sebebin yanı sıra, Müslümanların kadın haklarını ihlal ettiklerini düşündükleri ortaya konul- 
muştur (Noll vd, 2017). Hatta bazı araştırmalar göstermektedir ki İslam'dan çıkanların en fazla vurgu yaptıkları gerekçelerden biri, İslam'da kadın hakları ihlalleridir (Khalil ve Bilici, 2007). Müslüman toplumlarda kadının yerine dair bu bakış açısı, Müslüman kadınların örtünmelerinin erkek baskısıyla gerçekleştiğini iddiasını beraberinde getirmektedir. Nitekim Moaddel (2013) tarafından Müslüman çoğunluğa sahip 7 ülkede yapılan araştırmada katılımcılara "kadınlar nasıl giyineceklerine kendileri karar vermeli midir" diye sorulduğunda bu soruya evet diye cevap verenlerin ülkelere göre dağılımları şöyle olmuştur: Tunus \%56, Türkiye \%52, Lübnan \%49, Suudi Arabistan \%47, Irak \%27, Pakistan \%22 ve Mısır \%14. Görüldüŭü gibi Müslüman çoğunluğa sahip bazı ülkelerde toplumun çoğunluğu kadının nasıl örtüneceği konusunda söz hakkı olduğunu düşünürken, bazılarında bu oran dramatik düzeyde düşüktür. Bu durumda, kadınların, dinin emri olduğu için mi, erkeklerin baskısıyla mı, kültürel sebeplerle mi, yoksa estetik kaygılarla mı başlarını örttükleri birer soru olarak karşımızda durmaktadır.

Bugün dünyada çok sayıda Müslüman kadın başını örtmektedir. Türkiye'de başını örtme oranının \%60 ile \%70 arasında olduğu tahmin edilmektedir (Çarkoğlu ve Toprak, 2006, s. 59; KONDA, 2007, s. 10; DiB, 2014, s. 106). Müslüman kadınların başlarını örtme gerekçeleri birçok araştırmaya konu olmuştur. Diyanet İşleri Başkanlığı tarafından 2013 yılında Türkiye genelinde 37624 kişinin katıımıyla gerçekleştirilen araştırmada katıımcılara kadınların başlarını örtme gerekçeleri sorulduğunda sebepler ve yüzdeleri şöyle sıralanmıştır (DiB, 2014, s. 107):

a. Dini inançları gereği $-91,8$

b. Ailesi/eşi istediği için $-1,8$

c. Gelenek ve göreneklerden ötürü $-5,9$

d. Çevre baskısından $-0,1$

e. İş/okul gereği-0,0

f. Güzel görünmek için-0,1

g. Sağlık sebebiyle $-0,0$

h. Diğer sebepler-0,1

i. Fikrim yok $-0,1$

Bu araştırma, Türkiye'de başını örten kadınların çok büyük bir oranının $(\% 91,8)$ dini inançlarından ötürü başlarını örttüklerine dair algıyı göstermektedir. KONDA tarafından 2007 yılında 41 ilde 5291 kişinin katılımıyla gerçekleştirilen bir araştırmada kadınların başlarını örtme nedenleri sorulduğunda, katıımcıların \%73'ü dini inançlarını, \%13,7'si gelenek/göreneği, \%4,6'sı alışkanlıkları, $\% 3,1^{\prime} i$ çevreye uyumu, \%2,9'u aile büyüklerinin taleplerini ve \%2,7'si eşin isteğini gerekçe göstermiştir. Görüldüğü gibi burada da en yüksek orana sahip örtünme gerekçesi dini inançlardır. Başını örtmede, evliliğin veya diğer bir ifadeyle eşin isteği önemli midir diye bakıldığında, başını örtenlerin 
yaklaşık \%60'ının evlenmeden önce de başını örttüğü tespit edilmiştir. Evlendikten sonra başını örtenlerin oranı yalnızca \%13,2'dir (KONDA, 2007, s. 22).

Çarkoğlu ve Toprak (2006), yaptıkları araştırmada katılımcılara kadınların niçin örtündüklerini sormuştur. Başını örten kadınların \%71,5'i, dini inançları gereği başlarını örttüklerini söylemişlerdir. Bu oran, KONDA'nın (2007) araştırma verileriyle uyumludur. Bu araştırmada çarpıcı bir sonuç, başını örtmeyenlerin (katılımcı erkek ise eşi veya nişanlısı başını örtmeyenlerin) örtünme gerekçelerine dair fikirleridir. Başını örtmeyenlerin \%43,6'sı örtünenlerin dini inançları gereği örtündüklerini ifade etmiştir. Görüldüğü gibi, başını örten ve örtmeyenler, örtünme gerekçeleri konusunda farklı algılara sahiptir. Bunun muhtemel sebeplerinden biri, Türkiye'de kadınların örtünmelerinin siyasi/ideolojik tercihlerle (Subaşı, 2000) ve dindarlık düzeyleriyle ilişkili görülmesidir. Örtünme davranışı ile dindarlık düzeyi arasında ilişki olduğu düşünüldüğü için, örtünme konusundaki araştırmalar bu ilişkiyi de incelemektedir. Dindarlık ile başını örtme arasındaki ilişkiye bakıldığında, dindarlık arttıkça başını örtme oranının da arttığı görülmektedir (KONDA, 2007, s. 21; DiB, 2014, s. 106). Bu veriler, kadınların başları örtmelerinin birçok farklı sebebi olabileceğini ve bunun birçok değişkenle ilişkili olduğunu göstermektedir. Müslüman kadınların yalnızca ataerkil toplumsal yapı nedeniyle başlarını örttükleri, başını örtmenin kadınların istekleri dışında gerçekleştiğini ve erkeklerin bu konuda baskıları olduğunu söylemek indirgemeci bir yaklaşım olacaktır. Bunun yanı sıra, kadın örtünmesi konusunda cinsiyetçi bir tavrın, yani erkeğin kadından üstün görülmesinin ve erkeğin kadının yaşamında karar verici olduğunun düşünülmesinin söz konusu olabileceği gerçeğini de göz önünde bulundurmak gerekir.

Yukarıdaki ayetlerle ilgili ikinci husus, bu ayetlerde örtünmenin tarzına dair çok detaylı bilgi verilmemesidir. Başını örtme konusunda Müslüman kadınların çoğunluğu hemfikir gibi gözükmektedir. Fakat Özek'in (2013), belirttiği gibi bu ayetlerde örtünme emredilse de bunun sınırlarının ne olduğu konusunda mezhepler arasında bazı farklar vardır ve giyim tarzının nasıl olması gerektiği konusunda farklı yorumlar yapılmıştır. Bu nedenle günümüz Müslüman toplumlarına bakıldığında, giyim konusunda kuralları olan diğer dinler gibi, standart bir örtünme tarzından bahsedilememektedir. Müslüman kadınlar, bazı toplumlarda bütün vücutlarını kapatan kıyafetler giyerken, bazılarında saçlarının bir kısmı gözükecek şekilde başlarını örtmekle yetinmektedir. Örtünme tarzları ve bu tarzları nelerin belirlediği bir merak konusudur.

Moaddel (2013) tarafından, 2013 yılında, Müslüman çoğunluğa sahip 7 ülkede (Tunus, Mısır, Türkiye, Suudi Arabistan, Pakistan, Lübnan, Irak), 3019 kişinin katılımıyla gerçekleştirilen araştırmada, önce Müslüman kadınlar arasında yaygın olan 6 örtünme tarzı (en kapılıdan açığa doğru) tespit edilmiş ve sonra bu örtünme tarzlarının ülkelere göre tercih edilme düzeyleri incelenmiştir. Bu araştırmada örtünme tarzları burka (1- burqa), peçe (2- niqab), çarşaf (3- chador), türban (4- alamira), başörtüsü (5- hijab) ve açık (6- none) şeklinde belirlenmiştir. 
Tablo 1. Ülkelere Göre Örtünme Tarzları (Moaddel, 2013, s. 55)

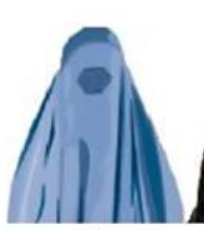

1

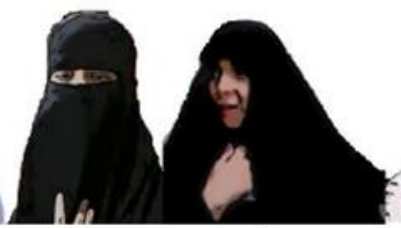

2
3

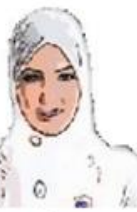

4

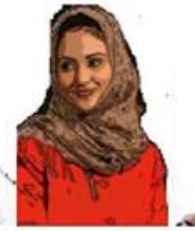

5

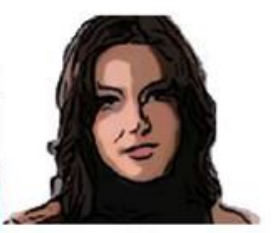

6

\begin{tabular}{|c|c|c|c|c|c|c|c|}
\hline Tunus & $\% 1$ & $\% 2$ & $\% 3$ & $\% 57$ & $\% 23$ & $\% 15$ & $\% 100$ \\
\hline Mısır & $\% 1$ & $\% 9$ & $\% 20$ & $\% 52$ & $\% 13$ & $\% 4$ & $\% 100$ \\
\hline Türkiye & $\% 0$ & $\% 2$ & $\% 2$ & $\% 46$ & $\% 17$ & $\% 32$ & $\% 100$ \\
\hline Irak & $\% 4$ & $\% 8$ & $\% 32$ & $\% 44$ & $\% 10$ & $\% 3$ & $\% 100$ \\
\hline Lübnan & $\% 2$ & $\% 1$ & $\% 3$ & $\% 32$ & $\% 12$ & $\% 49$ & $\% 100$ \\
\hline Pakistan & $\% 3$ & $\% 32$ & $\% 31$ & $\% 24$ & $\% 12$ & $\% 2$ & $\% 100$ \\
\hline $\begin{array}{l}\text { Suudi } \\
\text { Arabistan }\end{array}$ & $\% 11$ & $\% 63$ & $\% 8$ & $\% 10$ & $\% 5$ & $\% 3$ & $\% 100$ \\
\hline Ortalama & $\% 2$ & $\% 8$ & $\% 8$ & $\% 44$ & $\% 12$ & $\% 4$ & $\% 100$ \\
\hline
\end{tabular}

Tablo 1'de görüldüğü üzere, genel olarak en fazla tercih edilen örtünme tarzı 4 numaradır. 6 numaranın en fazla tercih edildiği ülkeler Türkiye ve Lübnan iken, 2 ve 3 numaranın en fazla tercih edildiği ülkeler Pakistan ve Suudi Arabistan'dır. Bu tarzlar, en kapalıdan açığa doğru bir skala oluşturacak şekilde sıralanmıştır. Bu araştırmada örtünme tercihleri aslında kadının vücudunun ne kadarının kapatılması gerektiğiyle ilgili tercihi de gözler önüne sermektedir.

Farklı örtünme tarzlarının evvela kültürel farklııılardan kaynaklandığı söylenebilir. Birçok araştırmacı (Dağ, 1982; Bağcı, 2006, Ünal, 2001) İslamiyet öncesi Arap toplumunda kadınların örtündügünü, hatta yüzlerini örtecek tarzda peçe (niqab) kullandıklarını ve bu örtünme biçiminin İslamiyet sonrasında da varlığını sürdürdüğünü belirtmektedir. Nitekim Moaddel'in (2013) araştırmasında da Arap topluluklarda peçenin (niqab) oldukça yüksek bir orana sahip olduğu gösterilmektedir.

Körfez ülkelerinde (Kuveyt, Bahreyn, Katar, BAE) kadınların giyim tercihlerini ele alan Kelly (2010), kültür ve sosyal bağlamın, örtünme tercihlerini belirlediğini, ama özellikle de bağlamın belirleyici olduğu ifade etmektedir. Buna göre, kadınların giyim tarzını belirleyen asıl unsur din değildir. Örneğin Kuveyt'te kadınların tercih ettiği abaya, Kuveytli kadınları Kuveytli olmayanlardan ayırt etme işlevi görmektedir. Ayrıca kadınların giyim tarzları, onların şehirli mi yoksa bedevi mi olduklarını ortaya koyan birer gösterge mahiyetindedir. Kelly (2010), kıyafet tercihlerinin dini gerekçelerinin olmasının yanında, ekonomik sınıf, politik tercih ve kültürle ilişkili olduğunu tespit etmiştir.

Örtünme tarzlarını belirleyen muhtemel bir başka neden, modern yaşam tarzı ve bununla birlikte ortaya çıkan modadır. Günümüzde Müslüman kadınlar geleneksel giyim tarzının dışında, 
günümüz modern yaşam biçimiyle daha uyumlu yeni İslami giyim tarzları ortaya koymaya başlamıştır. Akou'nun (2007) dediği gibi dünyada Batılı giyim modasının yanında artık İslami giyim modası olgusundan bahsetmek mümkündür. İslami giyim modasıyla ilgili günümüzde çeşitli dergiler, yüzlerce web sayfası, yüzlerce giyim firması faaliyet yürütmektedir. Türkiye, doğu ile batı arasında bir köprü olması hasebiyle yeni İslami giyim modasının önemli merkezlerinden biri haline gelmiştir (s. 404-405). Gökarıksel ve Secor (2010), özellikle 1980'li yıllardan sonra çok sayıda İslami giyim firmasının açıldığını, bu firmaların ve İslami modanın gittikçe yaygınlaştığını, fakat öte yandan bu durumun, tesettürün anlamı konusunda bir tartışmayı beraberinde getirdiğini belirtmektedir. Çünkü örtünen kadınlardan bazıları, yeni İslami giyim modasının, tesettürün asıl gerekçesiyle örtüşmediğini düşünmektedir. Türkiye'de ve diğer Müslüman ülkelerde bu yeni İslami giyim modası, bazı dini çevrelerce eleştirilmekte ve kadınların geleneksel tarzda giyinmeleri gerektiği savunulmaktadır.

Ataerkil kültürlerde, erkeklerin örtünmeye ilişkin tercihleri, kadınların örtünme tarzlarını belirleyecek bir etken olabilir. Moaddel'in (2013) araştırmasında örtünme tercihleri cinsiyet değişkeni bakımından incelenmiştir. Buna göre hemen her ülkede 4 numaralı örtünme tarzını kadınlar erkeklerden daha fazla tercih etmiştir. Pakistan ve Suudi Arabistan hariç diğer 5 ülkede ise erkekler 5 numarayı kadınlardan daha fazla tercih etmiştir. Görüldüğü gibi genel olarak kadınlar erkeklere göre daha kapalı bir modeli tercih etmişlerdir. Bu veri, erkek baskısıla kapanmanın gerçekleşmiş olacağı iddiasını zayıflatmaktadır. Öte yandan araştırmada, "nasıl kapanacağına kadın karar verir" cümlesine katılanların oranı yalnızca Tunus (\%56) ve Türkiye'de (\%52) yüzde ellinin üzerindedir ( s. 59). Bu oran, diğer İslam ülkelerine göre yüksek sayılsa da kadının kendi giyimine ilişkin tercih hakkı söz konusu olduğunda düşük kabul edilebilecek bir orandır. Pew Research Center (2013) tarafından Müslüman çoğunluğa sahip 39 ülkede gerçekleştirilen bir araştırmada kadınların peçe (veil) takmaya kendilerinin karar verip veremeyeceği sorulduğunda "bu kadının karar vermesi gereken bir şeydir" diyenlerin oranları Türkiye'de \%90 iken, diğer ülkelerde şu şekilde tespit edilmiştir: Tunus \%89, Lübnan \%61, Irak \%45, Pakistan \%70 ve Mısır \%46. Bu veri bize, örtünüp örtünmeme konusunda kadına daha az söz hakkı verilmesine rağmen, örtünme tarzı konusunda kadına daha fazla söz hakkı verildiğini göstermektedir. Ayrıca her iki araştırma verisi de kadınların giyim konusunda özgür olması bakımından Türkiye'nin diğer Müslüman ülkelerden ayrıştığını ve örtünme tarzları ile cinsiyetçilik arasında ilişki olabileceğini göstermektedir.

Bu bilgiler ışığında, kadınların örtünmelerinin ve örtünme tarzlarının birçok değişkenle ilişkili olabileceği fikrine ulaşmak mümkündür. Dini inançlar, örtünme gerekçeleri arasında önemli bir yer tutarken, dindarlık düzeyi, dini yorum, kültür, ataerkil toplumsal yapı, moda, coğrayfa, sosyoekonomik düzey gibi pekçok faktör kadınların örtünme davranışlarına etki etmektedir. Türkiye'de kadınların örtünme davranışlarına ilişkin veri sunması açısından bilinen grup (ilahiyat öğrencileri) davranışlarının incelenmesi, din eğitiminin, cinsiyetin, dindarlık düzeyinin örtünme konusundaki etkilerini daha açık bir şekilde ortaya koymaya yardım edecektir. 


\section{Yöntem}

\subsection{Araştırma Soruları ve Hipotezler}

Yukarıda ele alınan veriler ışığında, çeşitli sorular gündemimize gelmektedir. Kadınların kapanmaları, sadece İslami nedenlerle talep edilen bir şey midir yoksa bu konuda cinsiyetçi bir tutum söz konusu mudur? Dindarlık düzeyi ile örtünme tercihleri arasında bir ilişki var mıdır? Din eğitimi alan bireyler genel popülasyona göre örtünme nedenleri ve tarzları konusunda ne düşünmektedir? Din eğitimi, dindarlık, yaş, eğitim düzeyi gibi değişkenler bakımından homojen olan bir grupta, cinsiyet değişkeni bakımından kadının örtünmesine ilişkin tercihler nasıl değişmektedir? Örtünme nedenleri ile örtünme tarzları arasında bir ilişki var mıdır? Bu sorulara cevap aramak için ilahiyat fakültesinde okuyan öğrencilerin katıımıyla araştırma gerçekleştirilmiştir. Bu araştırmada, din(i) eğitim(i) alan ilahiyat fakültesi öğrencilerinin genel popülasyona kıyasla kadının başını hangi tarzda örtmesi gerektiğini düşündükleri ele alınmıştır. Ayrıca, kadın ve erkek öğrencilerin tercihleri arasındaki farklar incelenerek, cinsiyet değişkeninin etkisi araştırılmıştır. Türkiye'de kadınların hangi gerekçelerle başlarını örttüklerine dair katıımcıların fikirleri alınarak, bu örtünme tarzını İslam’a uygun bulup bulmadıkları da incelenmiştir. Araştırmanın hipotezleri şu şekildedir:

H1: İlahiyat fakültesi öğrencileri çoğunlukla 4 numaralı örtünme tarzını tercih etmektedir.

H2: Dindarlık düzeyi ile daha kapalı örtünme tarzları arasında pozitif bir ilişki vardır.

H3: Erkek öğrenciler, kadın öğrencilere göre daha kapalı örtünme tarzlarını daha İslami bulmaktadır.

H4: Erkek öğrenciler, kadın öğrencilere göre, kadının giyimi konusunda daha fazla söz hakları olduğunu düşünmektedir.

\subsection{Katılımcilar}

Bu araştırmanın evrenini, ilahiyat fakültesi öğrencileri oluşturmaktadır. Örneklem olarak Çanakkale Onsekiz Mart Üniversitesi İlahiyat Fakültesi'nde okuyan öğrenciler arasından rast gele 512 kişi seçilmiş ve 2017 yılında bu kişilere anket uygulanmıştır. Illahiyat fakültelerinde "ilahiyat" ve "ilköğretim Din Kültürü ve Ahlak Bilgisi Öğretmenliği” (DKAB) olmak üzere iki lisans programı bulunmaktadır. Araştırmaya her iki lisans programı da dahil edilmiştir. Anket formları incelendiğinde 7 kişinin soruları tamamlamadığı görülmüş bunlar araştırmaya dahil edilmemiştir. Böylece araştırma 505 örneklem sayısı ile tamamlanmıştır.

\subsection{Prosedür ve Ölçme Araçları}

Araştırmada kullanılmak üzere bir anket formu hazırlanmıştır. Anket formunun başında kişisel bilgileri (cinsiyet, yaş, gelir düzeyi, yerleşim birimi, lisans programı) almaya yönelik sorular yer almaktadır. Daha sonra ise dindarlık ölçeği, örtünme tarzlarına dair sorular ve diğer anket soruları gelmektedir. Birer çıktı şeklinde sorular öğrenciler dağıtılmış ve gönüllülük esasına göre anonim olarak formları doldurmaları istenmiştir. Bu formalar önce bilgisayar ortamına aktarılmış ve daha sonra SPSS programı yardımıyla veriler analiz edilmiştir. 
Anket formuna 6 farklı örtünme tarzını gösteren ve Moaddel (2013) tarafından kullanılan resim eklenmiştir. Öğrencilere bunlardan hangisinin İslam'a daha uygun bir giyinme tarzı olduğu sorulmuştur. Bu resmin kullanılmasındaki amaç, elde edilecek verilerin Moaddel'in araştırma verileriyle karşılaştırılmasıdır.

Katıımcıların dindarlık düzeylerini belirlemek için İçsel Dini Yönelim Ölçeği (Intrinsic Religious Motivation Scale) uygulanmıştır. Grubun dindarlık düzeyi bakımından homojen olabileceği düşünülerek katılımcıların içgüdümlü dindarlık yönelimleri ölçülmüştür. Hoge (1972) tarafından geliştirilen ölçek, içgüdümlü dindarlığı ölçmektedir. Ölçek, Allport ve Ross tarafından geliştirilen dini yönelim ölçeklerinin içgüdümlü dini yönelim altboyutlarıyla yüksek pozitif korelasyona (,71 ve ,87) ve yüksek iç güvenirlik katsayısına (,90) sahiptir (Hill ve Hood, 1999, s. 135-137). Karaca (2001) ölçeği Türkçeye uyarlamış, geçerlik ve güvenirlik analizlerini yapmıştır. Karacanın araştırmasında ölçeğin içsel tutarlıı̆̆ı 0,84 ve güvenirlik katsayısı 0,76 olarak bulunmuştur. Ölçekten yüksek puan alınması yüksek içgüdümlü dindarlığı göstermektedir.

Bu araştırmada, ölçeğin faktör analizine uygunluğuna bakıldığında Kaiser-Mayer-Olkin değeri ,870 ve Bartlett's Test of Sphericity değer 1109,810 p<,001 olarak bulunmuştur. Ölçek tek faktörden oluşmaktadır. Güvenirlik analizi sonucunda Cronbach Alfa değeri ,769 olarak tespit edilmiştir.

\section{Bulgular ve Tartışma}

Araştırmaya katılanların demografik verileri incelendiğinde, katılımcıların \%41'inin erkek ve yaş ortalamasının 22,5 (SD=2,4) olduğu tespit edilmiştir. Katılımcıların çoğunluğu, hayatlarının büyük bölümünü bir ilçede $(\% 29,7)$ ve ilde $(\% 47,9)$ geçirmiştir. Gelir düzeyi, alt-üst-orta şeklinde sıralandığında, katılımcıların \%89'unun orta gelir düzeyinde olduğu görülmektedir. Katılımcıların \%94'ü bekârdır. Lisans programlarına göre dağılıma bakıldığında ise katılımcıların \%80,4'ünün ilahiyat lisans programına ve $\% 18,2$ 'sinin ise DKAB'a devam ettiği görülmüştür.

Öğrencilerin giyim tarzlarına dair tercihleri, araştırmanın ana konularından birini oluşturmaktadır. Öğrencilere, 6 farklı giyim tarzı gösterilmiş ve bunlardan hangisinin İslam'a daha uygun olduğu sorulmuştur. 
Grafik 1. Öğrencilerin Örtünme Tarzına İlişkin Görüşleri



Elde edilen verilere bakıldığında (Grafik 1), öğrencilerin \% 59,01 gibi bir çoğunlukla 4 numaralı tarzı tercih ettikleri görülmektedir. Bu veriler, ilahiyat öğrencilerinin çoğunlukla 4 numaralı örtünme tarzını tercih ettikleri şeklindeki hipotezi $(\mathrm{H} 1)$ doğrulamaktadır. 4 numaralı tarzın çoğunlukla tercih edilmesi Moaddel'in (2013) araştırmasıyla uyumlu bir sonuçtur. Fakat diğer tarzların tercih edilme oranlarına bakıldığında ilahiyat fakültesi öğrencilerinin genel popülasyondan ayrıldıkları söylenebilir. Tablo 2'de görüldüğü üzere, Türkiye genelinde açık giyim tarzı \%32 oranında tercih edilirken, ilahiyat fakültesi öğrencilerinde bu oran yalnızca \%1,78'dir. Yine 2 ve 3 numaralı örtünme tarzları Türkiye genelinde yalnızca \%2 oranında tercih edilirken, ilahiyat öğrencilerinde bu oranlar 2 numaralı tarzda \%7,92'ye ve 3 numaralı tarzda \%19,41'e yükselmektedir.

Tablo 2. Genel Popülasyonun ve İlahiyat Öğrencilerinin Karşılaştırılması

\begin{tabular}{lccccccc}
\hline \hline & $\mathbf{1}$ & $\mathbf{2}$ & $\mathbf{3}$ & $\mathbf{4}$ & $\mathbf{5}$ & $\mathbf{6}$ & \\
\hline Türkiye geneli & $\% 0$ & $\% 2$ & $\% 2$ & $\% 46$ & $\% 17$ & $\% 32$ & $\% 100$ \\
illahiyat Öğrencileri & $\% 3,56$ & $\% 7,92$ & $\% 19,41$ & $\% 59,01$ & $\% 4,55$ & $\% 1,78$ & $\% 100$ \\
\hline
\end{tabular}

İlahiyat fakültesi öğrencileri daha kapalı giyim tarzlarını İslam’a daha uygun buldukları için, genel olarak Türkiye'deki kadın giyiminin İslam’a uygun olup olmadığı konusunda ne düşündükleri de bir merak konusudur. Bu nedenle araştırmada öğrencilere, "Türkiye'de kadınların giyim tarzları İslam'a uygun mudur" diye sorulmuştur. Cevaplar, "evet", "hayır", "kısmen" şeklinde kapalı uçlu olarak alınmıştır. Verilen yanıtlar analiz edildiğinde, katılımcıların \%2,18'inin "evet" dediği, buna karşın \%42,18'inin ise "hayır" şıkkını işaretlediği tespit edilmiştir. Bu veri, ilahiyat fakültesi öğrencile- 
rinin büyük kısmının, Türkiye'deki kadınların giyim tarzını İslam’a uygun bulmadıklarını göstermektedir. Bunun yanında öğrenciler, Türkiye'de kadınların giyim tarzını önemsemektedirler. Bu tespit, öğrencilere yöneltilen "çevrenizdeki insanların giyim tarzları sizin için önemli midir" sorusuna verilen yanıtlarla ortaya çıkmaktadır. Bu soruya "evet" diyenlerin oranı $(\% 35,25)$, "hayır" diyenlerin oranından $(\% 25,74)$ fazladır. Ayrıca öğrencilere, "çevrenizdeki insanların giyim tarzları İslam’a uygun değilse, onları uyarmanız gerektiğini düşünür müsünüz" sorusu yöneltilmiştir. Bu soruya verilen yanıtlara bakıldığında "evet" \%23,76, "hayır" \%26,34, "kısmen" \%48,91 olarak bulunmuştur.

Kadınların örtünmesiyle ilgili Türkiye'de yapılan araştırmalarda önemli konu başlıklarından biri, kadınların niçin örtündükleridir. Daha önce değinildiği gibi, Türkiye'de insanların çoğu, kadınların dini inançları gereği örtündüklerini söylemektedir (\%70 ile \%90 arası). Başını örtmeyen (kendisi veya eşi) kesimde, dini inançları gerekçe gösterme oranı düşmektedir. Aynı soru ilahiyat fakültesi öğrencilerine de yöneltilmiştir. ${ }^{1}$

Grafik 2. Türkiye'de Kadınların Örtünme Gerekçeleri

\begin{tabular}{|c|c|c|c|c|c|c|c|c|c|}
\hline \multirow[t]{2}{*}{$\begin{array}{r}100 \\
90 \\
80 \\
70 \\
60 \\
50 \\
40 \\
30 \\
20 \\
10 \\
0\end{array}$} & I. & $-a_{1}$ & $\mathrm{E}$ & $-\square \square$ & & & & $=$ & $\begin{array}{l} \\
- \\
-\end{array}$ \\
\hline & $\begin{array}{c}\text { Dini } \\
\text { inançlar } \\
\text { I gereği }\end{array}$ & $\begin{array}{l}\text { Ailesi/e } \\
\text { şi } \\
\text { istediği } \\
\text { için }\end{array}$ & $\begin{array}{l}\text { Gelene } \\
\text { k ve } \\
\text { görene } \\
\text { klerden } \\
\text { ötürü }\end{array}$ & $\begin{array}{c}\text { Çevre } \\
\text { baskısın } \\
\text { dan }\end{array}$ & $\begin{array}{l}\text { İş/okul } \\
\text { gereği }\end{array}$ & $\begin{array}{l}\text { Güzel } \\
\text { görünm } \\
\text { ek için }\end{array}$ & $\begin{array}{c}\text { Sağlık } \\
\text { sebebiy } \\
\text { le }\end{array}$ & $\begin{array}{c}\text { Diğer } \\
\text { sebeple } \\
r\end{array}$ & $\begin{array}{c}\text { Fikrim } \\
\text { yok }\end{array}$ \\
\hline DiB (2014) & 91,8 & 1,8 & 5,9 & 0,1 & 0 & 0,1 & 0 & 0,1 & 0,1 \\
\hline KONDA (2007) & 73 & 5,6 & 13,7 & 3,1 & & & & 4,6 & \\
\hline Çarkoğlu ve Toprak (2006) & 71,5 & 1,1 & 7,3 & 8,8 & & & & 5,5 & \\
\hline — ilahiyat Öğrencileri & 36,6 & 9,9 & 37,2 & 7,1 & 0,2 & 2,8 & 0,2 & 1,4 & 2,6 \\
\hline
\end{tabular}

Grafik 2'de yer alan oranlar karşılaştııılığında, ilahiyat fakültesi öğrencilerinin Türkiye'de kadınların örtünme gerekçelerine dair, Türkiye genelinden oldukça farklı düşündüğü ortaya çıkmaktadır. Türkiye'de insanların çoğu, kadınların dini inançları gereği örtündüklerini düşünürken, ilahiyat fakültesi öğrencilerinin çoğu $(\% 37,2)$ Türkiye'de kadınların gelenek/görenekten ötürü örtündüklerini düşünmektedir. Katılımcıların büyük oranda, Türkiye'de kadınların giyim tarzını İslam’a uygun

\footnotetext{
${ }^{1}$ Bu araştırmada, kadınların örtünme gerekçelerine ilişkin sorular DiB (2014) tarafından yapılan araştırmadan alınmıştır. KONDA (2007) ve Çarkoğlu \& Toprak (2006) tarafından yapılan araştırmalarda farklı sorular sorulmuştur. Verilerin karşılaştırılabilmesi için KONDA ve Çarkoğlu \& Toprak'ın araştırmasındaki veriler, bu araştırmada kullanılan en uygun seçeneklere yerleştirilmiştir.
} 
bulmadıkları göz önünde bulundurulursa, kadınların dini inançlardan ötürü değil, kültürel olarak örtündüklerini düşünmeleri olasıdır. Özellikle de daha kapalı modelleri tercih etmeleri, Türkiye'deki geleneksel örtünme tarzını İslam’a uygun bulmama sebeplerini açıklayabilir.

İlahiyat öğrencilerinin daha kapalı modelleri genel popülasyona göre daha fazla tercih etmesi, genel popülasyonun giyim tarzını İslam'a uygun bulmaması ve genel popülasyonun örtünme nedeninin dini olmaktan ziyade kültürel olduğunu düşünmesi, bu öğrencilerin din(i) eğitimi almalarıyla ilişkili olabilir. Bu noktada, dindarlık düzeyi ile örtünme tercihleri arasında ilişki olup olmadığı akla gelmektedir. Bu olguyu araştırmak için, katıımcılara İçsel Dini Yönelim Ölçeği uygulanmıştır. Bu ölçekte en yüksek puan 5 ve en düşük puan 1'dir. 5 puan, yüksek içsel dini yönelim olduğu anlamına gelmektedir. Örtünme tarzları ise en kapalıdan (6) en açığa doğru (1) bir skala oluşturacak şekilde puanlandığında, dindarlık ile örtünme tarzı arasında pozitif anlamlı bir korelasyon olduğu tespit edilmiştir ( $r=, 250 p<, 01)$. Bu veri bize, ilahiyat fakültesi öğrencilerinde dindarlık düzeyi arttıkça daha kapalı örtünme tarzlarının tercih edildiğini göstermektedir ve $\mathrm{H} 2$ hipotezi doğrulanmıştır.

Araştırmamız açısından en önemli başılıklardan biri, cinsiyet ile örtünme arasındaki ilişkidir. Bu olguyu araştırmak için öncelikle öğrencilere fakültelerindeki kızların ve erkeklerin giyimini İslam’a uygun bulup bulmadıkları ayrı ayrı sorulmuştur. Fakültedeki erkeklerin giyimini İslam'a uygun bulanların oranı \%21,98 iken, kızların giyimini İslam'a uygun bulanların oranı yalnızca \%13,86'dır. Erkeklerin giyim tarzı İslam'a daha uygun bulunmaktadır. Bunun muhtemel sebeplerinden biri, kadınların geleneksel olmayan örtünme tarzlarını tercih etmesi olabilir. İnformel gözlemlerimiz, bazı dini çevrelerde bazı örtünme tarzlarının İslam'a uygun bulunmadığı yönünde bir kanaatin oluştuğu yönündedir. Bu olguyu tespite yönelik olarak, kadın ve erkeklerin hangi örtünme tarzını İslam'a daha uygun buldukları verisi cinsiyet değişkeni bakımından incelenmiştir.

Grafik 3. Cinsiyete Göre Örtünme Tarzlarının Tercih Edilme Oranları

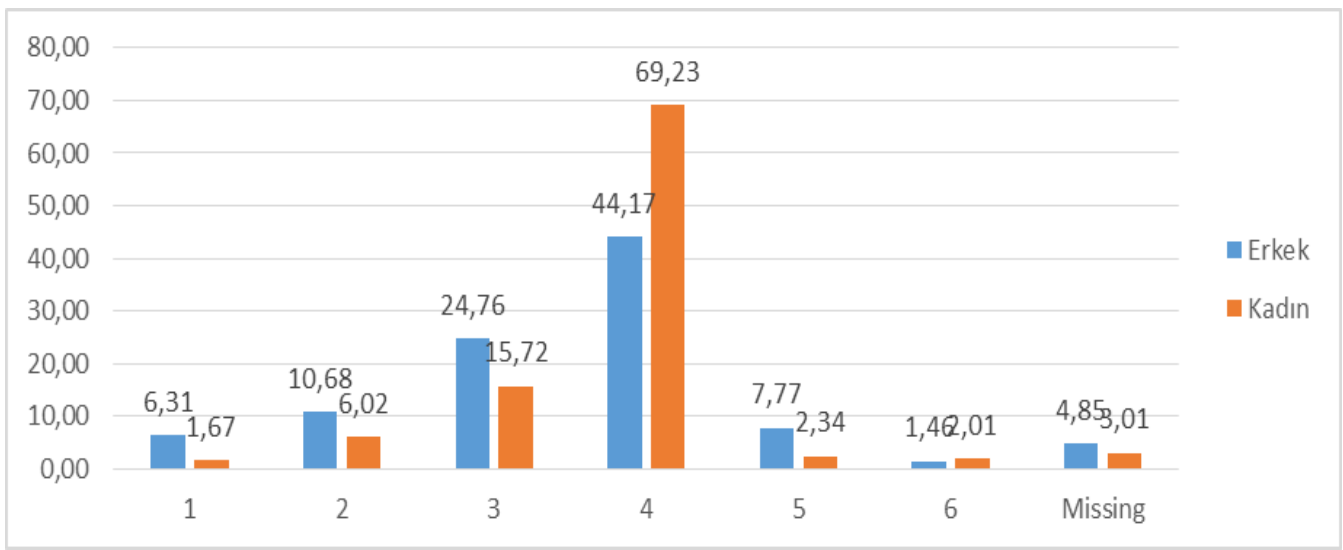

Grafik 3'de görüldüğü gibi, kadın öğrencilerin çoğunluğu $(\% 69,23) 4$ numaralı tarzı tercih etmektedir. Erkeklerin 4 numaralı tarzı tercih etme oranı $(\% 44,17)$, kadıların bu tarzı tercih etme 
oranından düşüktür. Asıl çarpıcı olan sonuç ise 1, 2 ve 3 numaralı tarzların erkekler tarafından daha yüksek oranda tercih edilmesidir.

Tablo 3. Cinsiyet Değişkeni Bakımından Giyim Tarzı Tercihlerinin Karşılaştırılması

\begin{tabular}{|c|c|c|c|c|c|c|c|c|c|}
\hline & & & \multicolumn{6}{|c|}{ "Giyim Tarzı } & \multirow[b]{2}{*}{ Toplam } \\
\hline & & & 1,00 & 2,00 & 3,00 & 4,00 & 5,00 & 6,00 & \\
\hline \multirow[t]{6}{*}{ Cinsiyet } & Erkek & Sayı & 13 & 22 & 51 & 91 & 16 & 3 & 196 \\
\hline & & $\begin{array}{l}\text { Cinsiyet } \\
\text { içindeki oran }\end{array}$ & $6,6 \%$ & $11,2 \%$ & $26,0 \%$ & $46,4 \%$ & $8,2 \%$ & $1,5 \%$ & $100,0 \%$ \\
\hline & & $\begin{array}{l}\text { Giyim Tarzı } \\
\text { içindeki oran }\end{array}$ & $72,2 \%$ & $55,0 \%$ & $52,0 \%$ & $30,5 \%$ & $69,6 \%$ & $33,3 \%$ & $40,3 \%$ \\
\hline & Kadın & Sayı & 5 & 18 & 47 & 207 & 7 & 6 & 290 \\
\hline & & $\begin{array}{l}\text { Cinsiyet } \\
\text { içindeki oran }\end{array}$ & $1,7 \%$ & $6,2 \%$ & $16,2 \%$ & $71,4 \%$ & $2,4 \%$ & $2,1 \%$ & $100,0 \%$ \\
\hline & & $\begin{array}{l}\text { Giyim Tarzı } \\
\text { içindeki oran }\end{array}$ & $27,8 \%$ & $45,0 \%$ & $48,0 \%$ & $69,5 \%$ & $30,4 \%$ & $66,7 \%$ & $59,7 \%$ \\
\hline \multirow[t]{3}{*}{ Toplam } & & Sayı & 18 & 40 & 98 & 298 & 23 & 9 & 486 \\
\hline & & $\begin{array}{l}\text { Cinsiyet } \\
\text { içindeki oran }\end{array}$ & $3,7 \%$ & $8,2 \%$ & $20,2 \%$ & $61,3 \%$ & $4,7 \%$ & $1,9 \%$ & $100,0 \%$ \\
\hline & & $\begin{array}{l}\text { Giyim Tarzı } \\
\text { içindeki oran }\end{array}$ & $100,0 \%$ & $100,0 \%$ & $\begin{array}{r}100,0 \\
\%\end{array}$ & $100,0 \%$ & $100,0 \%$ & $100,0 \%$ & $100,0 \%$ \\
\hline
\end{tabular}

Chi-kare değeri: $36,998, p<, 001$

Kadın ve erkeklerin örtünme tarzları konusundaki tercihleri arasındaki farkın anlamlı olup olmadığını tespit etmek için Chi-kare testi yapılmıştır (Tablo 3). Elde edilen sonuçlar, bu farkın anlamlı olduğunu göstermektedir ( $p<, 001)$.

Tablo 4. Cinsiyet Açısından Giyim Tarzının Kapalılık/Açıklık Oranının Karşılaştırılması

\begin{tabular}{lccccc}
\hline Cinsiyet & $N$ & Ort & \multicolumn{1}{c}{$S D$} & $t$ & \multicolumn{1}{c}{ p } \\
\hline Erkek & 196 & 3,4286 & 1,06217 & 3,586 &, 000 \\
Kadın & 290 & 3,7276 &, 77477 & & \\
\hline
\end{tabular}

Giyim tarzını en kapalıdan (1 puan) en açığa doğru ( 6 puan) bir skala oluşturacak şekilde puanladığımızda, erkeklerin ortalaması $(3,42)$ kadınların ortalamasından $(3,72)$ düşük çıkmaktadır (Tablo 4). Yani erkekler daha kapalı model tercih etmektedir. Bu iki ortalama arasındaki farkın anlamlı olup olmadığını tespit etmek için bağımsız örneklem t-test yapıldığında, farkın anlamlı olduğu görülmektedir ( $p<, 001)$. Yani kısacası, erkekler kadınlara göre daha kapalı örtünme tarzlarının İslam’a daha uygun olduğunu düşünmektedir. Bu veri, H3 hipotezini doğrulamakta ve örtünme tarzları konusunda cinsiyetçi bir tavrın olabileceğini akla getirmektedir. 
Grafik 4. Cinsiyete Göre, Kadınların Giyimini İslam’a Uygun Bulma Oranları

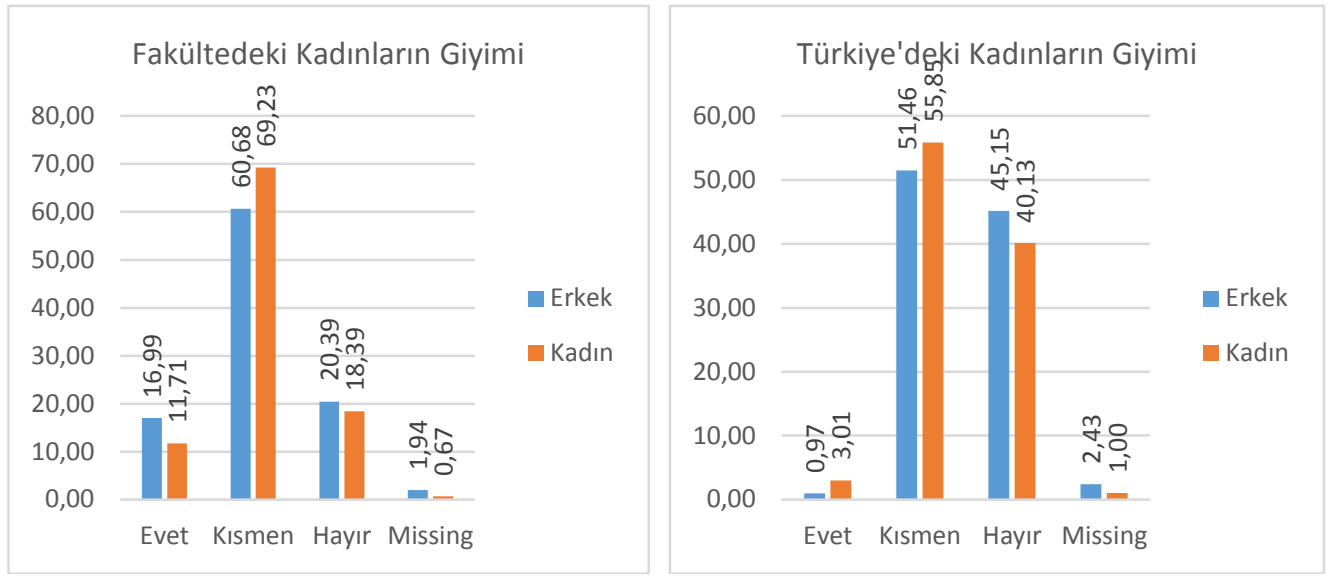

Öğrencilere "fakültenizdeki kadınların giyimi İslam'a uygun mu" diye sorulduğunda bu soruya erkekler \%20,8 ve kadınlar \%18,5 oranında "hayır" demiştir. Yani erkekler fakültedeki kadınların giyiminin İslam’a daha az uygun olduğunu düşünmektedir. Ancak iki grup arasındaki bu fark istatistiksel olarak anlamlı değildir. Aynı şekilde Türkiye'deki kadınların giyimlerinin İslam’a uygun olup olmadığı sorulduğunda yine erkeklerin \%46,3'ü buna hayır derken kadınların \%40,5'i hayır demiştir. Her iki durumda da, kendi giyim tarzlarıyla ilgili bir meselede kadınlar daha olumlu düşünürken, erkekler hem fakültedeki hem de Türkiye'deki kadınların İslam'a uygun giyinmediğini kadınlardan daha yüksek oranda düşünmektedir. Bu veriler, örtünme tarzı konusundaki tercihlerde cinsiyetçi bir yönün olabileceği fikrini desteklemektedir. Nitekim erkek öğrenciler arasında, fakültedeki kadınların giyimlerinin İslam'a uygun olduğunu düşünenlerin oranı \%17,3 iken, erkeklerin giyimlerinin İslam'a uygun olduğunu düşünenlerin oranı \%31'dir. Yine, erkek öğrenciler arasında Türkiye'de kadınların giyimlerinin İslam’a uygun olduğunu düşünenlerin oranı \%1 iken, erkeklerin giyimlerinin İslam'a uygun olduğunu düşünenlerin oranı \%16,7'dir. Erkekler, erkeklerin giyim tarzından çok, kadınların giyim tarzı konusunda endişeli gözükmektedir.

Erkeklerle kadınlar arasında, çevredeki insanların giyim tarzlarıyla alakadar olma konusunda bir fark var mıdır? Erkekler çevrelerindeki insanların giyimleri konusunda daha duyarlı olabilir mi? Bu araştırmada katılımcılara, "çevrenizdeki insanların giyim tarzı sizin için önemli midir" diye sorulmuş ve bu soruya verilen yanıtlar cinsiyet değişkeni bakımından analiz edilmiştir. 
Kenan SEVINÇ

Tablo 5. Cinsiyete Göre Çevredeki İnsanların Giyim Tarzını Önemseme Düzeyleri

\begin{tabular}{|c|c|c|c|c|c|c|}
\hline & & & \multicolumn{3}{|c|}{ Çevrenin Giyim Tarzı Önemli mi? } & \multirow[b]{2}{*}{ Toplam } \\
\hline & & & Evet & KIsmen & Hayır & \\
\hline \multirow[t]{6}{*}{ Cinsiyet } & Erkek & Sayı & 87 & 71 & 45 & 203 \\
\hline & & Cinsiyet içinde & $42,9 \%$ & $35,0 \%$ & $22,2 \%$ & $100,0 \%$ \\
\hline & & $\begin{array}{l}\text { Giyim Tarzı } \\
\text { Önemi içinde }\end{array}$ & $48,9 \%$ & $37,0 \%$ & $34,6 \%$ & $40,6 \%$ \\
\hline & Kadın & Sayı & 91 & 121 & 85 & 297 \\
\hline & & Cinsiyet içinde & $30,6 \%$ & $40,7 \%$ & $28,6 \%$ & $100,0 \%$ \\
\hline & & $\begin{array}{l}\text { Giyim Tarzı } \\
\text { Önemi içinde }\end{array}$ & $51,1 \%$ & $63,0 \%$ & $65,4 \%$ & $59,4 \%$ \\
\hline \multirow[t]{3}{*}{ Toplam } & & Sayı & 178 & 192 & 130 & 500 \\
\hline & & Cinsiyet içinde & $35,6 \%$ & $38,4 \%$ & $26,0 \%$ & $100,0 \%$ \\
\hline & & $\begin{array}{l}\text { Giyim Tarzı } \\
\text { Önemi içinde }\end{array}$ & $100,0 \%$ & $100,0 \%$ & $100,0 \%$ & $100,0 \%$ \\
\hline
\end{tabular}

Chi-Kare: $8,030 p<, 05$

Tablo 5'te görüldüğü gibi, "çevrenizdeki insanların giyim tarzları sizin için önemli midir" sorusuna erkeklerin \%42,9'u, kadınların ise yalnızca \%30,6'sı "evet" demiştir. Cinsiyetler arasındaki bu fark Chi-kare testi sonuçlarına göre anlamlıdır $(p<, 05)$. Görüldüğü gibi erkekler kadınlara oranla, çevrelerindeki insanların giyimini daha fazla önemsemektedir. Bu önemseme, davranışlara da etki etmekte midir? Bunu araştırmak için öğrencilere "çevrenizdeki insanların giyim tarzları İslam’a uygun değilse, onları uyarmanız gerektiğini düşünür müsünüz" diye sorulmuş ve cevaplar cinsiyete göre analiz edilmiştir. Tablo 6'da görüldüğü gibi, kadın ve erkek öğrenciler arasında bu soruya "evet" diyenlerin oranları birbirine çok yakındır.

Tablo 6. Cinsiyete Göre Çevredeki İnsanları Uyarma Gereği Duyma Düzeyleri

\begin{tabular}{|c|c|c|c|c|c|c|}
\hline & & & \multicolumn{3}{|c|}{ Ç̧evredekileri uyarır mısınız? } & \multirow[b]{2}{*}{ Total } \\
\hline & & & Evet & Kısmen & Hayır & \\
\hline \multirow[t]{6}{*}{ Cinsiyet } & Erkek & Sayı & 49 & 87 & 67 & 203 \\
\hline & & Cinsiyet içinde & $24,1 \%$ & $42,9 \%$ & $33,0 \%$ & $100,0 \%$ \\
\hline & & Uyarma içinde & $40,8 \%$ & $35,2 \%$ & $50,4 \%$ & $40,6 \%$ \\
\hline & Kadın & Sayı & 71 & 160 & 66 & 297 \\
\hline & & Cinsiyet içinde & $23,9 \%$ & $53,9 \%$ & $22,2 \%$ & $100,0 \%$ \\
\hline & & Uyarma içinde & $59,2 \%$ & $64,8 \%$ & $49,6 \%$ & $59,4 \%$ \\
\hline \multirow[t]{3}{*}{ Toplam } & & Sayı & 120 & 247 & 133 & 500 \\
\hline & & Cinsiyet içinde & $24,0 \%$ & $49,4 \%$ & $26,6 \%$ & $100,0 \%$ \\
\hline & & Uyarma içinde & $100,0 \%$ & $100,0 \%$ & $100,0 \%$ & $100,0 \%$ \\
\hline
\end{tabular}

Chi-kare: $8,235 p<, 05$ 
Bu araştırmada, son olarak, katılımcıların kadınların örtünme gerekçelerine dair cevapları cinsiyet değişkeni bakımından incelenmiştir. Tablo 7'de görüldüğü gibi, her iki grupta da en yüksek oran "gelenek ve göreneklerden ötürü" seçeneğine aittir. Kadınlar da erkekler de Türkiye'de kadınların çoğunlukla geleneksel olarak örtündüklerini düşünmektedir. Öte yandan, "dini inançları gereği” seçeneğini işaretleyenler arasında kadınların oranı \%62,7 iken, erkeklerin oranı \%37,3’tür. Yani, kadınlar erkeklere göre daha yüksek oranda dini inançlar gereği örtünmenin olduğunu düşünmektedir. Buna karşın "çevre baskısından" ve "güzel görünmek için" seçeneklerini işaretleyenler arasında erkeklerin oranı kadınlardan fazladır. Kısacası bu oranlar, kadın öğrencilerin erkek öğrencilere göre örtünme gerekçeleri arasında dini inancalara daha fazla vurgu yaptığını, erkeklerin ise diğer sebeplere vurgu yaptı̆ı̆ını göstermektedir.

Tablo 7. Cinsiyete Göre Kadınların Örtünme Gerekçelerine Dair Düşünceler

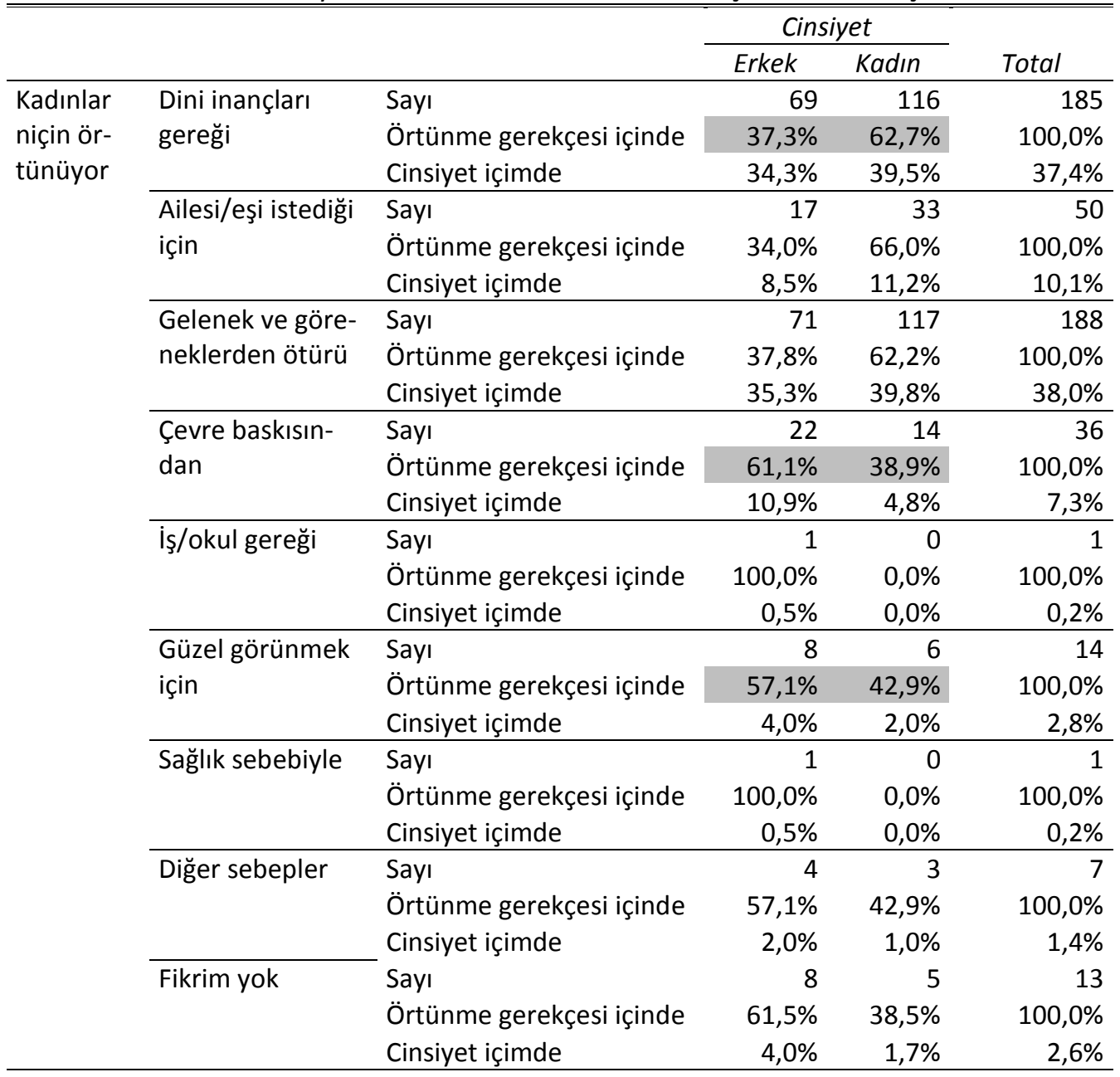


Kenan SEVINÇ

\begin{tabular}{llrrr}
\hline Toplam & Sayı & 201 & 294 & 495 \\
& Örtünme gerekçesi içinde & $40,6 \%$ & $59,4 \%$ & $100,0 \%$ \\
& Cinsiyet içimde & $100,0 \%$ & $100,0 \%$ & $100,0 \%$ \\
\hline
\end{tabular}

Chi-kare: $16,318 p<, 05$

\section{Sonuç}

Müslüman kadınların örtünme gerekçelerini ve örtünmenin tarzını belirleyen çok sayıda faktör vardır. Başta dini inançlar ve dindarlık düzeyi olmak üzere, kültür, moda, coğrafya, sosyo-ekonomik düzey ve cinsiyetçi tutumlar bunlar arasında sayılabilir. Bu araştırmada, din(i) eğitimin(in), dindarlık düzeyinin ve cinsiyetin, kadınların örtünme davranışlarına nasıl bir etkide bulunduğu araştırıımıştır. Elde edilen sonuçlar, din(i) eğitim(i) alan ilahiyat fakültesi öğrencilerinin, Türkiye'deki genel popülasyona göre, kadınların daha kapalı tarzda örtünmelerinin İslam'a daha uygun olduğunu düşündüklerini ortaya koymuştur. Öğrenciler arasında dindarlık düzeyi arttıkça, daha kapalı örtünme tarzlarını tercih düzeyi de artmaktadır. İlahiyat fakültesi öğrencilerinin genel olarak Türkiye'de kadınların örtünme tarzlarını İslam’a çok uygun bulmadıkları ve Türkiye'de kadınların dini inançlardan ziyade geleneksel olarak başlarını örttüklerini düşündükleri söylenebilir.

Cinsiyet değişkeni bakımından veriler incelendiğinde, erkek öğrencilerin kadın öğrencilere göre, kadınların daha kapalı giyinmeleri gerektiğini düşündükleri ortaya çıkmaktadır. Ayrıca, erkek öğrenciler, Türkiye'deki erkeklerin Türkiye'deki kadınlara göre İslam'a daha uygun giyindiklerini düşünmektedir. Öğrencilere, diğer insanların giyim tarzlarını önemseyip önemsemedikleri ve onlara müdahale edip edemeyecekleri sorulduğunda, yine erkek öğrencilerin kadın öğrencilere göre, çevredeki insanların giyimleri konusunda daha fazla söz hakları olduklarını düşündükleri ortaya çıkmışıı. Erkekler, kadınların nasıl giyinecekleri konusunda söz hakları olduklarını düşünmektedir. Bu sonuçlar, dini inançlarla birlikte ataerkil kültürün, kadının örtünmesine ve örtünme tarzına ne denli etkide bulunabileceğine dair ipuçları sunmaktadır.

Araştırmada örneklem bir fakülteden seçilmiştir ki araştırmanın en önemli kısıtılığının bu olduğu söylenebilir. Türkiye'de yüksek din eğitimi/öğretimi alan öğrencilerin kadınların örtünmesi konusunda ne düşündüklerini daha iyi tespit edebilmek için araştırma, diğer ilahiyat fakültelerinden örneklem alınarak genişletilebilir. Ayrıca, ilahiyat fakültesi öğrencileri ile genel popülasyonun daha sağlıklı bir şekilde karşılaştıııması için yine araştırmaya genel popülasyondan örneklem dahil edilebilir. İlahiyat fakültesinin öğretim programının öğrencilerin konuyla ilgili fikirlerinin oluşmasına etkisi olup olmadığını tespit etmek için boylamsal çalışmalara intiyaç vardır.

\section{Kaynaklar}

Akdemir, S. (1997). Tarih Boyunca ve Kur’an-ı Kerim'de Kadın. İslami Araştırmalar, 10(4), 249-258.

Akgül, M. (1998). The Status of Woman in Islam. Selçuk Üniversitesi Ilahiyat Fakültesi Dergisi, 8, 177-187. 
Akou, H. M. (2007). Building a New 'World Fashion': Islamic Dress in the Twenty-first Century. Fashion Theory, 11(4), 403-421.

Armaner, N. (1961). Hadislere Göre Kadının Sosyal Durumuna Umumi Bir Bakış. Ankara Üniversitesi Ilahiyat Fakültesi Dergisi, 9, 131-139.

Ateş, S. (1997). İslam'ın Kadına Getirdiği Haklar. İslami Araştırmalar, 10(4), 304-310.

Bağcı, M. (2006). Adetler ve ibadetler Arasında Peçe Sorunu. Dicle Üniversitesi Ilahiyat Fakültesi, $8(2), 21-45$.

Çarkoğlu, A. ve Toprak, B. (2006). Değişen Türkiye'de Din, Toplum ve Siyaset. İstanbul: Tesev Yayınları.

Dağ, M. (1982). İslam'da Örtünme Üzerine. İslam Ilimleri Enstitüsü Dergisi, 5, 187-191.

Dikmen, M. (1983). İslam'da Kadın Hakları. 2. Baskı, İstanbul: Cihan Yayınları.

Eskicioğlu, O. (1994). İslamda Kadının Yeri. DEÜ Ilahiyat Fakültesi Dergisi, 8, 85-120.

Gökarıksel, B. \& Secor, A. (2010). Between Fashion and Tesettür: Marketing and Consuming Women's Islamic Dress. Journal of Middle East Women'a Studies, 6(3), 118-148.

Görmez, M. (2001). İlahi Dinlere Göre Başörtüsü. İslâmiyât, 4(2), 19-33.

Hoge, D.R. (1972). A Validated Intrinsic Religious Motivation Scale. Journal for the Scientific Study of Religion, 11(4), 369-376.

Karaca, F. (2001). Din Psikolojisinde Metot Sorunu ve Bir Dindarlık Ölçeğinin Türk Toplumuna Standardizasyonu. EKEV Akademi Dergisi,2(4), 187-204.

Kelly, M. (2010). Clothes, Culture, and Context: Female Dress in Kuwait. Fashion Theory, 14(2), 215-263.

Khalil, M.H. \& Bilici, M. (2007). Conversion Out of Islam: A Study of Conversion Narratives of Former Muslims. The Muslim World, 97, 111-124.

Konda (2007). Gündelik Yaşamda Din, Laiklik ve Türban Araştırması. http://konda.com.tr/wpcontent/uploads/2017/03/2007_09_KONDA_Gundelik_Yasam.pdf adresinden elde edildi (Erişim: 27.10.2015).

Küçük, N. (2013). Gender Inequality in the MENA: Myths Versus Facts. Topics in Middle Eastern and African Economies, 15(2), 71-104.

Moaddel, M. (2013). The Birthplace of the Arab Spring: Values and Perceptions of Tunussians and A Comparative Assessment of Egyptian, Iraqi, Lebanese, Pakistani, Saudi, Tunisian, and Turkish Publics, Report by University of Michigan Middle Eastern Values Study, http://mevs.org/files/tmp/Tunisia_FinalReport.pdf adresinden elde edildi (Erişim: 20.11.2015). 
Noll, J.V., Saroglou, V., Latour, D., Dolezal, N. (2017). Western Anti-Muslim Prejudice: Value Conflict or Discrimination of Persons Too?. Political Psychology, 20(20), 1-21.

Özdeş, T. (2008). The Qur'an, Interpretation And The Mateer Of Gender. C.Ü. Ilahiyat Fakültesi Dergisi, 12(1), 407-438.

Özek, A. (2013). Ku'an'da Kadın ve Kadın Hakları. Kur'an ve Sünnete Göre Temel İnsan Hakları: Tartışmalı ilmi Toplantı, 21-22 Aralık 2013, Bağlarbaşı, İstanbul.

Pew (2013). The World's Muslims: Religion, Politics and Society. Pew Research Center, http://www.pewforum.org/2013/04/30/the-worlds-muslims-religion-politics-societyoverview/ adresinden elde edildi (Erişim: 28.01.2017).

Subaşı, N. (2000). 80'li Yıllarda Örtünmenin Anlamı. İslâmiyât, 3(2), 61-70.

Tozduman, A.Ş. (1991). İslam'da Kadın Hakları. 3. Baskı, İstanbul: Seha Neşriyat.

Ünal, i..H. (2001). Hadislere Göre Kadının Örtünmesi. İslâmiyât, 4(2), 53-68.

World Economic Forum (2016). The Global Gender Gap Report 2016, http://reports.weforum.org/global-gender-gap-report-2016/ adresinden elde edildi (Erişim: 17.09.2017).

Yılmaz, H. (2007). Hz. Peygamber Döneminden Günümüze Kadınlar ve Cami Eğitimi. Değerler Eğitimi Dergisi, 5(14), 107-130. 